\title{
Anesthesia scavenging in critical care areas: beware of possible hazards and questionable efficacy
}

\author{
Steven L. Dain, MD, FRCPC
}

Received: 7 July 2016/Revised: 9 July 2016/Accepted: 21 September 2016/Published online: 7 October 2016

(C) Canadian Anesthesiologists' Society 2016

\section{To the Editor,}

I applaud Wong et al.'s ${ }^{1}$ efforts to reduce anesthetic gas pollution when volatile anesthesia is used for sedation in the intensive care unit (ICU) and to keep the ICU's environmental levels below the recommended limit of two parts per million. However, I have several concerns in the way they attempted to achieve their goal.

1. They used the medical vacuum pipeline already present in critical care units even though it is not intended for anesthetic gas scavenging (AGS). Failing to use dedicated AGS pipelines is a potential safety hazard that contravenes national Canadian Standards Association $(\mathrm{CSA})^{\mathrm{A}}$ and Organization for International Standardization (ISO) ${ }^{\mathrm{B}}$ standards.

2. The use of medical vacuum pipelines for AGS is a potential fire and explosion hazard. The medical vacuum pump may use oil that, when in contact with an oxygen-enriched gas, may be explosive. AGS vacuum pumps do not use oil in contact with the gas stream and are specifically designed to be compatible with oxygen and anesthetic agents.

3. The medical vacuum system may not be capable of handling the additional flow of AGS from ICU ventilators.

4. Was there consultation with, and approval for, the AGS use of the medical vacuum by the "Qualified Person charged with the operation and management of

This letter is accompanied by a reply. Please see Can J Anesth 2017; 64: this issue.

S. L. Dain, MD, FRCPC ( $\square)$

Department of Anesthesia and Perioperative Medicine,

Woodstock Hospital, Woodstock, ON, Canada

e-mail: sdain@rogers.com the medical gas pipelines," as specified in CSA Z7396.1 ? $^{\mathrm{A}}$

5. Were the ventilators used in this study designed by the ventilator manufacturers to be used with an AGS system? Attaching any devices or accessories that are not intended and approved by the ventilator manufacturer and national regulatory bodies (e.g., Health Canada) may degrade the performance of the ventilator, potentially causing harm, void the ventilator warranty, and contravene the national regulations for medical devices. ${ }^{\mathrm{C}}$

6. Did the authors perform a comprehensive risk analysis according to ISO $14971^{\mathrm{D}}$ to ensure that the risks to the

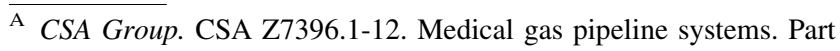
1: Pipelines for medical gases, medical vacuum, medical support gases, and anaesthetic gas scavenging systems, 2012. Canadian Standards Association, Rexdale, ON, Canada. Available from URL: http://www.techstreet.com/products/preview/1853251 (accessed July 2016).

B International Organization for Standardization. ISO 7396-2. Medical gas pipeline systems. Part 2: Anaesthetic gas scavenging disposal systems. Organization for International Standardization, Geneva, 2007. Available from URL: http://www.iso.org/iso/ catalogue_detail.htm?csnumber=41945 (accessed July 2016).

${ }^{\mathrm{C}}$ Health Canada. Available from URL: http://www.hc-sc.gc.ca/dhpmps/md-im/applic-demande/guide-ld/gd_rbc_non_ivdd_lg_scr_autres_ idiv-eng.php (accessed July 2016).

D International Organization for Standardization. ISO 14971. Medical devices. Application of risk management to medical devices. Geneva, 2007. Available from URL: http://www.iso.org/ iso/catalogue_detail?csnumber=38193 (accessed July 2016).
} 
patient, healthcare providers, and environment were as low as reasonably practicable?

7. The design and manufacturing of AGS systems are subject to national regulations for compliance with the Medical Device Act, ${ }^{\mathrm{E}}$ ISO $13485,{ }^{\mathrm{F}}$ and product licensing. Are the Deltasorb ${ }^{\circledR}$ canisters (Bluezone Technology, Concord, ON, Canada) that were used in this study registered class II medical devices?

In addition to the above concerns, the efficacy of the AGS system described seems uncertain. For example, the measured isoflurane levels in Table $1^{1}$ at the location distal to the Deltasorb ${ }^{\circledR}$ canisters were often greater than zero (studies 1, 2, 5, 15, 17, 19, 22, 13) and, curiously, sometimes greater or equal to that at the ventilator expiratory port (study 5 , days 1 and 2 ; study 2 , day 3 ), which suggests that the Deltasorb ${ }^{\circledR}$ material was either already saturated with anesthetic agent or non-functional. The poor efficacy of the AGS is likely due to the activated charcoal in the AnaConDa ${ }^{\circledR}$ (Anaesthetic Conserving Device, Sedana Medical, Sweden) scavenging the anesthetic.

If all of the proper steps were taken, and the ventilator was connected to a ventilator manufacturer-approved AGS interface with a CSA-approved AGS pipeline, the environmental measurements of isoflurane would likely be the same with or without the Deltasorb ${ }^{\circledR}$ canisters. Thus, Wong et al. have not convincingly shown that the efficacy of their simple, active AGS system for minimizing atmospheric pollution during long-term volatile anesthetic-based sedation in the ICU is in any way due to the Deltasorb ${ }^{\circledR}$ canisters.
In Wong's study, anesthetic agent passes through the Deltasorb $^{\circledR}$ canisters. Although Doyle et al. $^{2}$ in 2002 showed some efficacy up to $18 \mathrm{hr}$ with isoflurane $1 \%$, a study similar to that of Doyle et al. ${ }^{2}$ needs to be performed with sevoflurane and desflurane to determine the amount of anesthetic agent that the current 2016 Deltasorb ${ }^{\circledR}$ canisters actually collect. We need to know how much passes through the canisters over time into the AGS pipeline before any claims can be made about its efficacy.

In summary, anesthetic scavenging should be accomplished only using a CSA-approved AGS system. In addition, medical equipment should be used only for its licensed, intended purpose. The Deltasorb canisters do not add to the quality of the scavenging in the described system and might unnecessarily increase its complexity and cost.

Conflicts of interest None declared.

Editorial responsibility This submission was handled by Dr. Hilary P. Grocott, Editor-in-Chief, Canadian Journal of Anesthesia.

\section{References}

1. Wong K, Wasowicz M, Grewal D, et al. Efficacy of a simple scavenging system for long-term critical care sedation using volatile agent-based anesthesia. Can J Anesth 2016; 63: 630-2.

2. Doyle DJ, Byrick $R$, Filipovic D, Cashin F. Silica zeolite scavenging of exhaled isoflurane: a preliminary report. Can $\mathrm{J}$ Anesth 2002; 49: 799-804.

\footnotetext{
$\overline{\mathrm{E}}$ Government of Canada. Justice Laws website. Medical devices regulations. Available from URL: http://laws-lois.justice.gc.ca/eng/ regulations/sor-98-282/ (accessed July 2016).

F International Organization Standardization. ISO 13485:2016. Medical devices. Quality management systems: requirements for regulatory purposes. Geneva, 2016. Available from URL: http:// webstore.ansi.org/Previews/PREVIEW_ISO+13485-2016.pdf (accessed July 2016).
} 